ISSN: $2146-3042$

DOI: 10.25095/mufad.607218

\title{
Muhasebe Meslek Mensuplarının Sundukları Hizmet Kalitesinin Müşteri Memnuniyeti Üzerindeki Etkisi: Erzincan Örneği
}

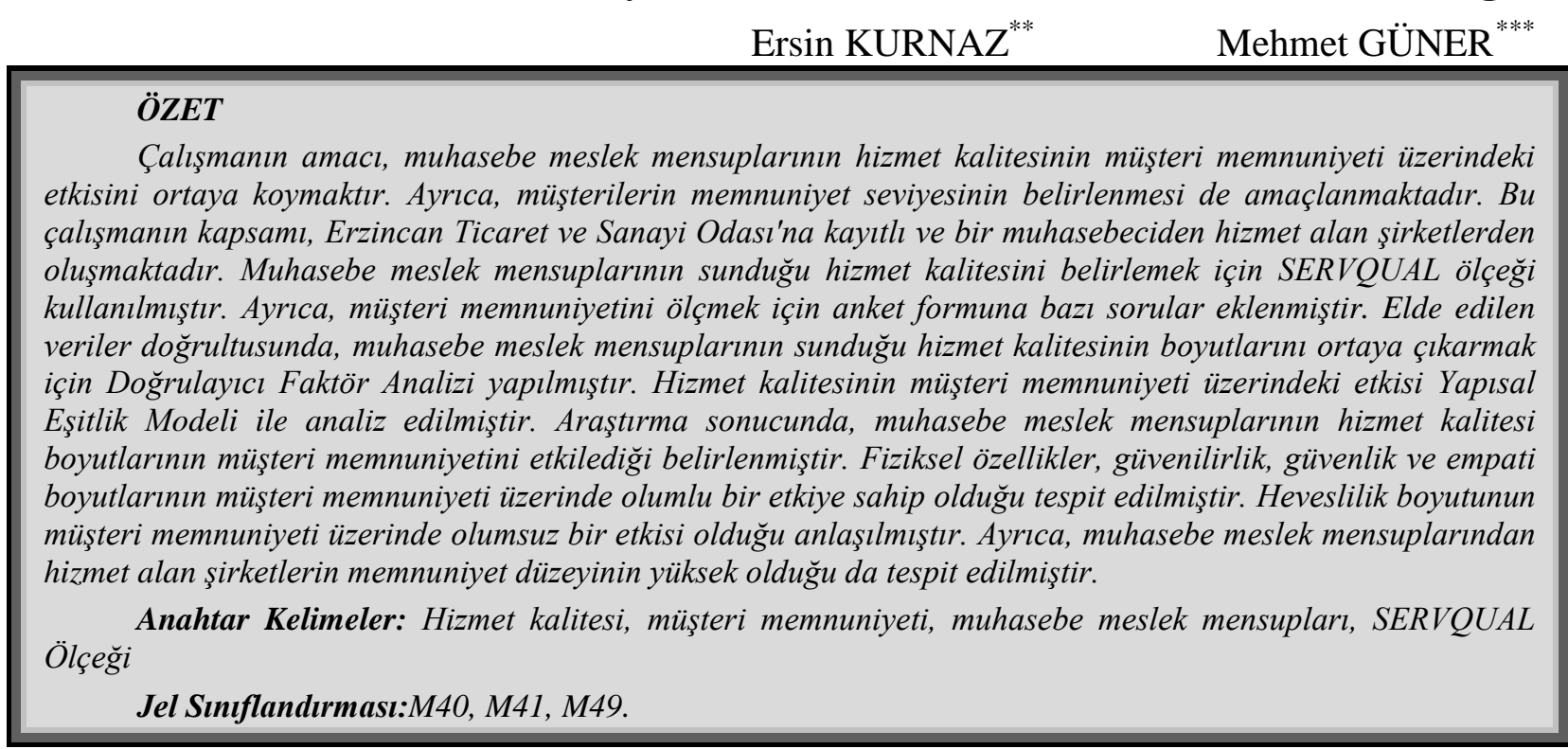

The Effect of Quality of Service Provided by Professional Accountants on Customer Satisfaction: Erzincan Sample

\section{ABSTRACT}

The aim of the study is to reveal the effect of service quality of Professional accountants on customer satisfaction. It is also aimed to determine the level of customer satisfaction. The scope of this study consists of the companies that are registered to Erzincan Chamber of Commerce and Industry and which are companies that receives service from a Professional accountant. SERVQUAL scale was used to determine the quality of service offered by Professional accountants. In addition, some questions have been included in the questionnaire form to measure customer satisfaction. In line with the data to be obtained, Confirmatory Factor Analyze was performed to reveal the dimensions of service quality offered by Professional accountants. The impact of service quality on customer satisfaction was analyzed by Structural Equation Model. As a result of the research, it has been determined that the dimensions of service quality of Professional accountants have an impact on customer satisfaction. It has been identified that physical properties, reliability, safety and empathy dimensions have a positive effect on customer satisfaction. It was understood that the dimension of enthusiasm had a negative impact on customer satisfaction. In addition, it has been determined that the satisfaction level of companies receiving service from Professional accountants is high.

Keywords: Service Quality, Customer Satisfaction, Professional Accountants, SERVQUAL Scale.

Jel Classification:M40, M41, M49.

Makale Gönderim Tarihi: 01.06.2019

Makale Kabul Tarihi: 01.08.2019

Makale Türü: Araştırma Makalesi

\footnotetext{
*** Assist Prof., Erzincan Binali Yıldırım Üniversitesi, İktisadi ve İdari Bilimler Fakültesi, mehmetguner@gmail.com, ORCID ID: 0000-0002-9523-1519
} 


\section{GİRIŞ}

İşletme faaliyetlerinin çeşidinin ve sayısının hızlı bir şekilde artış göstermesi, birçok iş akış sürecinin dijital ortamlara taşınması ve rekabetin artması gibi gelişmelere paralel olarak hizmet sektörünün sunduğu hizmetin ve kalitesinin önemi her geçen gün artmaktadır. Ayrıca, hizmet sektörünün ekonomi içindeki payının ekonomide bir kalkınmışlık göstergesi olarak kabul edilmesi de bu sektörün önemini ortaya koymaktadır.

Özellikle son yıllarda müşterilerin değişen tutumları, algıları ve beklentilerinin çeşitlilik göstermesi, kalite konusunu hizmet sektöründe olmazsa olmaz bir unsur haline getirmiştir. Nitekim kalite kavramının geçmişi sanayi devrimine kadar uzamaktadır. Sanayi devriminden günümüze kadar geçen sürede müşteri memnuniyetini ön planda tutan ve kaliteli hizmeti kurumsal yapılarının merkezine oturtan işletmeler, uzun yıllar ayakta kalarak sektörlerine liderlik etmişlerdir.

Sunulan hizmetin kalitesini belirleyen önemli faktörlerden birisi işletme sahip veya çalışanlarının hizmet kalitesi anlayışını gözeterek çalışmalarıdır. Dolayısıyla, işletmeler kaliteli hizmet sunmayı bir değer olarak tüm çalışanlarına benimsetmelidir. Ayrıca, günümüzde hayatın her alanında varlığını hissettiren dijital uygulamaları etkin bir şekilde kullanabilen ve yorumlayabilen yetkin bireyleri bünyelerinde bulundurmalıdırlar. Çünkü teknolojik gelişmeler, hizmet kalitesini etkileyen en önemli unsurların başında gelmektedir.

Üzerinde durulması gereken diğer bir konu ise, hizmet alan işletmelerin hizmet kalitesini nasıl algıladıklarıdır. Kuşkusuz alınan hizmetin kaliteli olup olamadığına karar verecek olan taraf müşteridir. Ancak, hizmet sektöründe hizmet kalitesinin ölçümü çok kolay değildir. Buna rağmen literatüre bakıldığında hizmet kalitesini ölçmek için birçok çalışma yapılmış ve ölçek geliştirilmiştir. Söz konusu ölçeklerden en çok kullanılan ve kabul gören ölçeklerden biride SERVQUAL ölçeğidir.

Hizmet sektöründe önemli bir payı ve yeri olan mesleklerden biride muhasebe meslek mensuplarıdır. Muhasebe meslek mensuplarının sunmuş oldukları hizmet, işletmeler için hayati öneme sahip olan mali konulara yönelik olduğu için bu meslekte çalışanların sunmuş olduğu hizmet kalitesi ve müşterilerinin memnuniyet düzeyi büyük önem arz etmektedir.

$\mathrm{Bu}$ çalışma ile SERVQUAL ölçeği kullanılarak muhasebe meslek mensuplarının sunduğu hizmet kalitesinin müşterilerinin memnuniyet düzeyi üzerindeki etkisinin ortaya konulması amaçlanmıştır. Bu kapsamda Erzincan Sanayi ve Ticaret Odasına kayıtlı ve aktif olarak faaliyet gösteren şirket statüsündeki işletmelere yönelik bir anket uygulanmıştır. Elde edilen veriler çeşitli analiz yöntemleriyle test edilerek muhasebe meslek mensuplarının sunduğu hizmetin kalitesi ortaya konulmaya çalışılmıştır.

\section{KAVRAMSAL ÇERÇEVE}

Literatürde hizmet kavramıyla ilgili birçok tanımlama yapılmıştır. Bunlardan bazıları şunlardır: Hizmet, tüketici ihtiyaçlarının karşılanması için meydana getirilen ve maddi niteliği olmayan bir üründür (Kuriloff vd.,1993: 247). Hizmet, tüketicilerin mülkiyetle herhangi bir ilişkisi olmaksızın satın aldıkları faydalardır (Mucuk, 1994; 319). Bir başka tanımda ise, müşteri için iş icra etmek şeklinde tanımlanmıştır (Goetsch ve Davis; 1998: 104). Hizmet 
sektöründe sunulan hizmetin çeşitli özelliklere bulunmaktadır. Bu özellikler; fiziksel varlığının olmaması (soyutluk), üretimle tüketimin birbirinden ayrılmaz olması (ayrılmazlık), değişkenlik, heterojenlik ve dayanıksızlık şeklinde sıralanabilir (Ghobadian vd., 1994:44-46).

Sunulan hizmetlerin karakteristik özellikleri, müşterilerin kalite algısını ve müşteri tatminini önemli ölçüde etkilemektedir. Örneğin, hizmetlerin soyut oluşu, müşterilerin satın almadan önce alacakları hizmetin kalitesini değerlendirmesini zorlaştırmaktadır. Birçok durumda ise, hizmet satın alınması ve kullanımı sonrasında da müşterilerin hizmet kalitesini değerlendirmeleri zor olabilmektedir. Aynı şekilde, hizmetlerde kalite kontrolü de son derece zordur(Tek, 1999:430). Algılanan hizmet kalitesi, müşterilerin hizmetin kalitesine yönelik sezgileri şeklinde tanımlanabilir. Ayrıca müşterilerin tatmin derecesini de önemli ölçüde belirleyen bir unsurdur (Ghobadian vd., 1994: 50).

Parasuraman, Zeithaml ve Berry'e göre, algılanan hizmet kalitesi, müşterilerin hizmetten beklentileri ile hizmet sunumu esnasında, hizmetin performansına yönelik oluşan algıların yönünün bir neticesidir (Parasuraman vd., 1985: 48-49). Parasuraman, Zeithaml ve Berry'e göre, genel olarak hizmet sunan işletmelerde geçerli olan beş hizmet kalitesi boyutu bulunmaktadır. Bu boyutlar aşağıda kısaca açıklanmıştır (Zeithaml vd., 1990: 176):

- $\quad$ Fiziksel Özellikler (Tangibles): İşletmenin hizmet sunmadaki fiziksel imkânları, araç gereç ve personelin görünüşü.

- Güvenilirlik (Reliability): Söz verilen hizmeti zamanında, doğru ve güvenilir bir şekilde yerine getirebilme.

- Heveslilik (Responsiveness): Çalışanların müşterilere yardım etmedeki istekliliği ve hizmetin hızlı bir şekilde verilmesi.

- $\quad$ Güven (Assurance): Hizmet sunan kişilerin

bilgili ve saygılı olması ve müşteriye güven duygusu verebilme yeteneği.

- Empati (Empathy): işletmenin kendisini müşterinin yerine koyması, müşterilere kişisel ilgi gösterilmesi.

Günümüz rekabet ortamında hizmet sunan firmalar müşterilerini tatmin etmek için kaliteli hizmet sunmalıdırlar. Hizmet kalitesi; maliyetler, karlılık, müşteri tatmini ve pozitif iletişimle olan yakın ilişkisi nedeniyle süreli araştırılması gereken konulardan biri olmuştur (Buttle, 1995: 8).

Hizmet sektöründe sunulan hizmetin temel özellikleri nedeniyle hizmetin kalitesini ölçmek oldukça zordur. Hizmet sektörünün bir parçası olan muhasebe meslek mensupları da, "hizmet" kavramının bütün özelliklerini taşımaktadır. Örneğin, muhasebe meslek mensupları müşterilerine sundukları danışmanlık hizmetleri, nakit yönetimi veya finansal tabloların analizi gibi hizmetler hizmetin soyut özelliğini taşırken, defter tutma, raporların hazırlanması, beyannamelerin düzenlenmesi gibi somut hizmetleri de sunabilmektedir. İşletmelerin büyüklükleri, hukuki yapıları, coğrafik koşulları gibi nedenlerle tüm işletmelere aynı reçetenin sunulamaması, hizmetlerin türdeş olmamasına neden olmaktadır. Ancak, muhasebenin önceden belirlenmiş ölçütler gibi zorlayıcı hükümleri gereği muhasebe meslek 
mensubu müşterilerine türdeş hizmetler de sunabilmektedir. Ayrıca, meslek mensuplarının sundukları hizmetin ayrılmazlığından da söz edilebilir. Eşzamanlı tüketimden (ayrılmazlık) kasıt, hizmetlerin müşteriye sunulması ile müşteri tarafindan kullanılmasının aynı anda olmasıdır. Müşterilere; denetim raporunun, finansal raporlarının veya danışmanlık hizmetinin sunulması eşzamanlılık ilkesine örnek olarak gösterilebilir (Banar ve Ekergil, 2010: 43).

\section{METODOLOJí}

Çalışmanın bu kısmında anket formu aracılığg ile şirketlerden elde edilen veriler analiz edilerek tespit edilen bilgi ve bulgular paylaşılacaktır.

\subsection{Araştırmanın Amacı ve Önemi}

Araştırmanın temel amacı, muhasebe meslek mensuplarının sunduğu hizmet kalitesinin müşterilerinin memnuniyet düzeyi üzerindeki etkisini ortaya koymaktır. Ayrıca, müşterilerin memnuniyet düzeyinin tespit edilmesi de tali bir amaç olarak belirlenmiştir. $\mathrm{Bu}$ amaç çerçevesinde araştırmanın çözüm aradığı sorular şu şekilde ifade edilebilir:

- $\quad$ Muhasebe meslek mensuplarının hizmet kalitesini ifade etmek üzere literatürde ifade edilmiş olan boyutlar geçerli midir? (Doğrulayıcı faktör analizi sonucunda belirlenmiştir.)

- Muhasebe meslek mensuplarının hizmet kalitesini ifade eden boyutlar ile müşteri memnuniyeti arasında bir ilişsi var mıdır? (Korelasyon analizi ile belirlenmiştir.)

- Muhasebe meslek mensuplarının hizmet kalitesinin müşteri memnuniyeti üzerindeki etkisi nedir? (Yapısal Eşitlik Modeli ile belirlenmiştir.)

Herhangi bir işletme için, ortaya konulan ürünün veya sunulan hizmetin kalitesi müşterileri tarafından arzu edilen ve beklenen en temel hususlardan birisidir. Tüketicilerin büyük çoğunluğu kaliteli ürün ve hizmetlere yönelmektedir. Mamul üreten işletmelerde ortaya çıkan ürünün kalitesinin tespit edilmesi ve müşteri beklentileri doğrultusunda geliştirilmesi hizmet üreten işletmelere nazaran çok daha kolay süreçtir. Hizmetin soyut yapısı kalitesinin tespit edilmesini de güçleştirmektedir. Doğrudan müşterilerin beklentilerinin ve hizmet kullanımı sonrasında algıladıkları kalitenin ölçülmesi suretiyle hizmet kalitesinin ortaya konulması mümkün olabilmektedir. $\mathrm{Bu}$ süreç, SERVQUAL vb. ölçeklerin geliştirilmesine ve hizmet kalitesinin bu ölçekler aracılığı ile ölçülmesine imkan tanımıştır. Algılanan kalitenin ölçülmesi sonucunda, işletmeler sundukları hizmet kalitesinin artırılması için gerekli adımları atarak rekabet avantajı sağlayabilirler. Araştırmada bir hizmet üretim işletmesi olarak ifade edilebilecek olan muhasebe meslek mensuplarının sundukları hizmet kalitesinin tespit edilmesi ve bunun müşteri memnuniyetine etkisinin şekillendirilmesi bu çalışmanın önemini ifade etmektedir. Ayrıca, müşteri memnuniyetinin belirlenecek olması da muhasebe meslek mensuplarına daha kaliteli hizmet sunmada rehberlik edecektir. İlgili literatür incelendiğinde, konu ile ilgili çalışmalar yapılmış olmakla birlikte muhasebe meslek mensupları üzerinde yeterli çalışma bulunmadığı ve bu alanda yapılan çalışmalarda ise yapısal eşitlik modellemesi ile detaylı bir analiz yapılmadığı gözlenmiştir. Bu çerçevede, söz konusu araştırmanın bir ilk niteliğinde olduğu söylenebilir. 


\subsection{Araştırmanın Kapsamı ve Yöntemi}

Araştırma kapsamını Ocak 2019 itibarı ile Erzincan ili merkezinde, Erzincan Sanayi ve Ticaret Odasına kayıtlı ve aktif olarak faaliyet gösteren şirket statüsündeki işletmeler oluşturmaktadır. Zaman ve maliyet kısıtlarından dolayı ilçelerde bulunan şirketler kapsam dışı bırakılmıştır. Bu kapsamda araştırma evrenini, söz konusu odaya kayıtlı 929 şirket oluşturmaktadır. 59 şirketin adres bilgileri oda kayıtlarında güncel olmadığı için bu işletmelerin iletişim bilgilerine ulaşılamamıştır. Gerekli geri dönüşün sağlanabilmesi için, 870 şirketin tamamına elektronik posta aracılığı ile anket formu gönderilmiştir. Bazı şirketlere ise yüz yüze anket uygulaması gerçekleştirilmiştir. 232 şirketten geri dönüş alınmış ancak, 17 anket formunun eksik ya da hatalı veriler içerdiği tespit edildiği için değerlendirme dışı bırakılmıştır. Dolayısıyla, 215 anket formundan elde edilen veriler kullanılmıştır.

Araştırma, anket yöntemi ile veri toplanması ve analiz edilmesine yönelik bir saha çalışması olarak kurgulanmıştır. Araştırmada 3 farklı ölçek kullanılmıştır. Muhasebe meslek mensubu tarafından sunulan hizmete yönelik algılanan hizmet kalitesinin ölçülmesi amacı ile 5'li Likert tipi ölçeğe göre uyarlanmış SERVQUAL ölçeğinden yararlanılmıştır. Ölçekte, 1-4 aras1 sorular (F1, F2, F3 ve F4) hizmet kalitesinin "fiziksel özellikler” boyutunu, 5-10 aras1 sorular (G1, G2, G3, G4, G5 ve G6) hizmet kalitesinin "güvenilirlik” boyutunu, 11-15 aras1 sorular (H1, H2, H3, H4 ve H5) "heveslilik" boyutunu, 16-19 aras1 sorular (GV1, GV2, GV3 ve GV4) "güvenlik" boyutunu ve 20-20 aras1 sorular (E1, E2, E3, E4 ve E5) "empati" boyutunu ölçmektedir. Muhasebe meslek mensubunun sunduğu hizmetten memnuniyet düzeyini ortaya koymak için Saxby vd. (2003) ile Banar ve Ekergil (2010) tarafindan da kullanılan 5'li Likert tipi ölçeğe göre hazırlanmış 6 ifadeden (M1, M2, M3, M4, M5 ve M6) oluşan bir ölçek kullanılmıştır. Katılımcıların demografik özelliklerini belirlemek için ise 7 ifadeden oluşan ölçek kullanılmıştır.

Veriler SPSS for Windows ve LISREL programları kullanılarak analiz edilmiştir. Araştırmanın bağımlı değişkeni muhasebe meslek mensubunun sunduğu hizmet neticesinde ortaya çıkan müşteri memnuniyeti, bağımsız değişkenleri ise müşteriler tarafından algılanan hizmet kalitesinin boyutları olan güvenilirlik, fiziksel özellikler, güvenlik, heveslilik ve empatidir.

\subsection{Araştırmanın Modeli ve Hipotezleri}

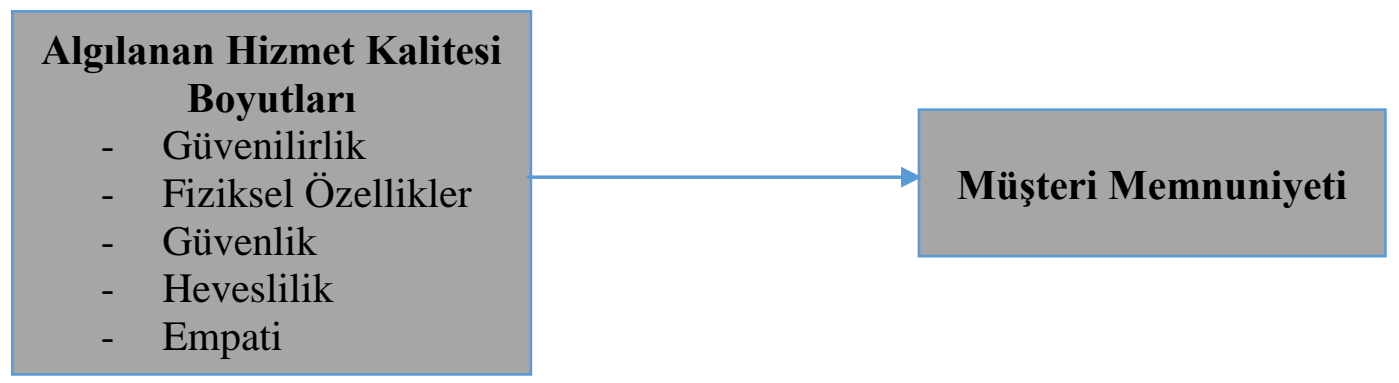

Şekil 1. Araştırmanın Modeli

Modelden hareketle araştırmanın ana hipotezi ve buna bağlı alt hipotezleri şu şekilde oluşturulmuştur: 
- $\quad \mathbf{H}_{1}$ : Müşteriler tarafindan algılanan hizmet kalitesi muhasebe meslek mensubunun oluşturduğu müşteri memnuniyetini etkilemektedir.

- $\quad \mathbf{H}_{1 \mathbf{a}}$ : Müşteriler tarafından algılanan hizmet kalitesinin güvenilirlik boyutu muhasebe meslek mensubunun oluşturduğu müşteri memnuniyetini etkilemektedir.

- $\quad \mathbf{H}_{1 \mathbf{b}}$ : Müşteriler tarafından algılanan hizmet kalitesinin fiziksel özellikler boyutu muhasebe meslek mensubunun oluşturduğu müşteri memnuniyetini etkilemektedir.

- $\quad \mathbf{H}_{\mathbf{1 c}}$ : Müşteriler tarafindan algılanan hizmet kalitesinin güvenlik boyutu muhasebe meslek mensubunun oluşturduğu müşteri memnuniyetini etkilemektedir.

- $\quad \mathbf{H}_{1 \mathbf{d}}$ : Müşteriler tarafından algılanan hizmet kalitesinin heveslilik boyutu muhasebe meslek mensubunun oluşturduğu müşteri memnuniyetini etkilemektedir.

- $\quad \mathbf{H}_{1 \mathbf{e}}$ : Müşteriler tarafindan algılanan hizmet kalitesinin empati boyutu muhasebe meslek mensubunun oluşturduğu müşteri memnuniyetini etkilemektedir.

\subsection{Araştırma Bulgularının Değerlendirilmesi}

Araştırmaya katılan şirketler, şirket çalışan ya da yetkililerineait bazı veriler ve hizmet kalitesinin müşteri memnuniyetine etkilerini ortaya koyan bulguların değerlendirilmesi bu kısımda sunulmuştur.

\subsubsection{Demografik Bulgular}

Tablo 1'de araştırmaya katılan şirketler ve şirketteki çalışan/yetkililerle ilgili bilgiler yer almaktadir.

Tablo 1:Demografik Bulgular

\begin{tabular}{|c|c|c|c|}
\hline \multicolumn{2}{|c|}{ Demografik özellikler } & $\mathbf{N}$ & $\%$ \\
\hline \multirow{3}{*}{ Cinsiyet } & Erkek & 175 & 81,4 \\
\hline & Kadın & 40 & 18,6 \\
\hline & Toplam & 215 & 100 \\
\hline \multirow{5}{*}{ Yaş } & $0-30$ aras1 & 63 & 29,3 \\
\hline & $31-40$ aras1 & 81 & 37,7 \\
\hline & $41-50$ aras1 & 50 & 23,3 \\
\hline & 51 ve üstü & 21 & 9,8 \\
\hline & Toplam & 215 & 100 \\
\hline \multirow{8}{*}{ Eğitim Durumu } & İlkokul & 13 & 6,0 \\
\hline & Ortaokul & 18 & 8,4 \\
\hline & Lise & 83 & 38,6 \\
\hline & Önlisans & 34 & 15,8 \\
\hline & Lisans & 56 & 26,0 \\
\hline & Yüksek Lisans & 11 & 5,1 \\
\hline & Doktora & 0 & 0 \\
\hline & Toplam & 215 & 100 \\
\hline \multirow{2}{*}{ Sektör } & Perakende/Toptan Ticaret & 64 & 29,8 \\
\hline & Sağl1k & 9 & 4,1 \\
\hline
\end{tabular}




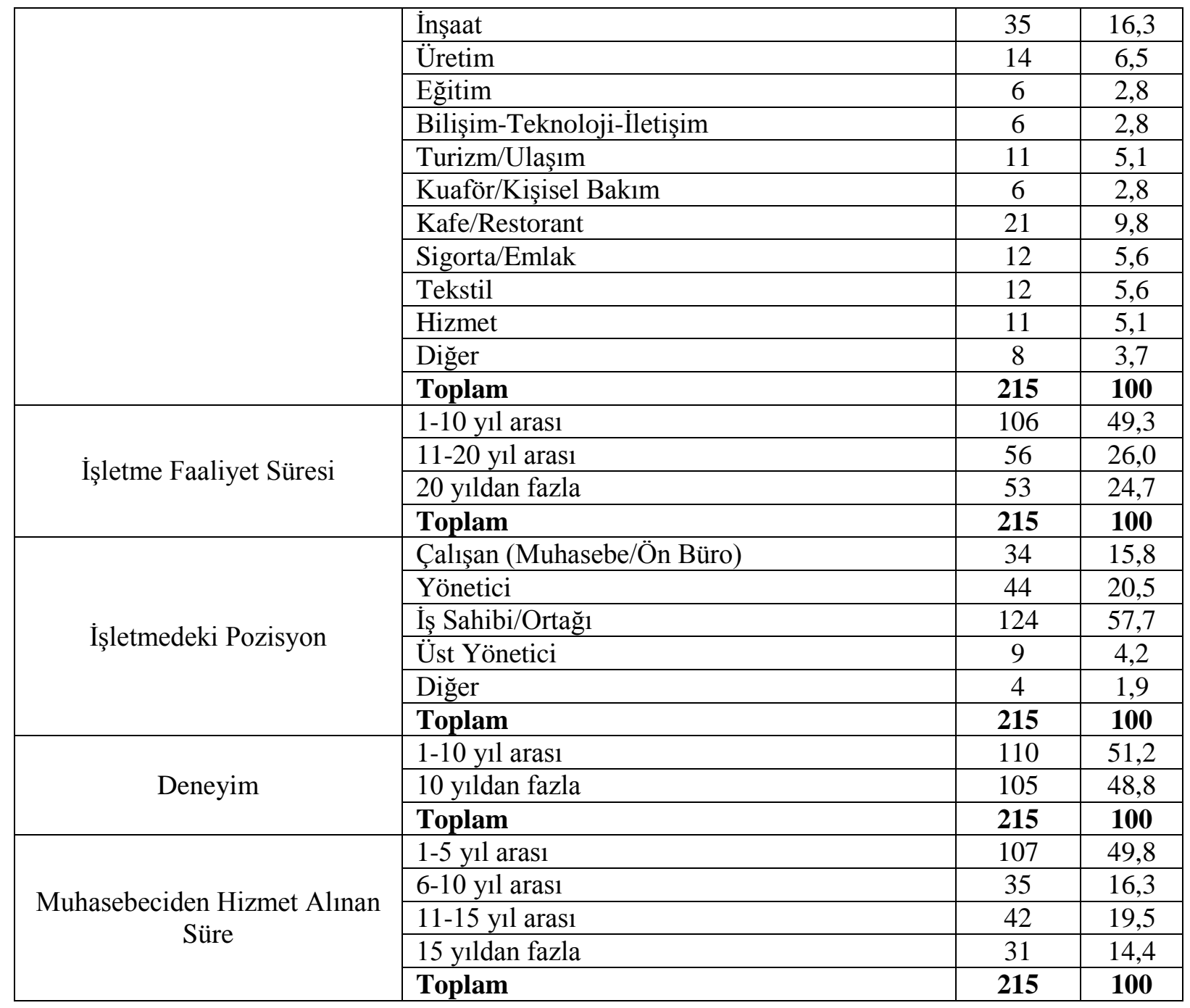

Anketi yanıtlayan şirketlerden alınan cevaplara göre Tablo 1 değerlendirildiğinde; katılımcıların \%81,4'ünün erkek, \%18.6'sının kadın olduğu ayrıca, \%29,3'ünün 0-30 yaş aras1, \%37,7'sinin 31-40 yaş arası, \%23,3'ünün 41-50 yaş arası ve \%9,8'inin 51 yaş üzeri olduğu görülmektedir. Katılımcıların büyük çoğunluğu erkek olmasına rağmen farklılık analizleri için yeterli sayıda kadın katılımcının olduğu da ifade edilebilir. Katılımcıların yaşları incelendiğinde ise çoğunluğun 31-40 yaş arasında olmakla birlikte dengeli sayılabilecek bir dağılım gösterdiği söylenebilir. Katılımcıların eğitim durumu incelendiğinde \%38,6'sının lise ve \%26'sının lisans mezunu olduğu, ilkokul $(\% 6)$ ve ortaokul $(\% 8,4)$ mezunlarının nispeten çok daha az olduğu görülmektedir. Bu bağlamda, katılımcıların anket sorularını sağlıklı bir şekilde cevaplamak için yeterli donanıma sahip olduğu söylenebilir. Sektörel dağ1lıma göre ise işletmelerin büyük çoğunluğunun perakende/toptan ticaret (\%64) ve inşaat (\%35) sektörlerinde faaliyet gösterdiği, bununla birlikte farklı kesimlerin görüşünü temsil etmek üzere birçok sektörden yeterli katılımcının bulunduğu ifade edilebilir. Anket uygulanan işletmelerin \%49,3'ü 1-10 yıl arası süreden beri faaliyet gösterirken kalan kısmı 11-20 yıl arası (\%26) ve 20 yıldan fazla $(\% 24,7)$ süreden beri faaliyetlerine devam etmektedir. $\mathrm{Bu}$ işletmelerde anketi cevaplayan kişilerin yaklaşık yarısı 1-10 yıl arası deneyime sahipken kalan yarısının deneyimi 10 yıldan fazladır. Katılımcıların büyük çoğunluğu anket yapılan işletmenin sahibi/ortağı $(\% 57,7)$ ya da yöneticisidir $(\% 20,5)$. Dolayısıyla, katılımcılar hem 
sektörü hem de işletmeleri tanımaktadır. Ayrıca, muhasebeciden alınan hizmetin kalitesini değerlendirebilecek deneyim ve donanıma sahip oldukları ifade edilebilir. Çalışma sonuçlarına önemli etkisi olacağı düşünülen muhasebeciden hizmet alınan süre incelendiğinde ise, işletmelerin yaklaşık yarısının $(\% 49,8)$ 1-5 yıldır aynı muhasebeci ile çalıştığı görülmektedir. Her ne kadar ilk bakışta bu durum olası bir memnuniyetsizlik nedeniyle sık muhasebeci değiştirme nedeniyle ortaya çıktığını gösterse de veriler incelendiğinde faaliyet süresi 1-5 yıl arası olan işletmelerin sayısının da fazla olduğu ve bu işletmelerin çoğunluğunun ilk hizmet aldıkları muhasebeci ile çalışmaya devam ettikleri gözlenmiştir. Dolayısı ile hizmet alınan sürenin kısalığının memnuniyetsizlikten kaynaklanmadığı ifade edilebilir.

\subsubsection{Doğrulayıcı Faktör Analizi ve Güvenilirlik}

Araştırmada kullanılan SERVQUAL ölçeği Parasuraman vd. (1985) tarafindan uzun yıllar önce geliştirilmiş ve birçok çalışmada hizmet kalitesini ölçmek üzere kullanılmıştır. Ölçekteki ifadeler hizmet kalitesinin unsurlarını ifade eden 5 boyut (Fiziksel özellikler, güvenilirlik, heveslilik, güvenlik ve empati) altında toplanmıştır. Ölçeğin boyutları daha önce birçok çalışmada ortaya koyulmuş ve kendini ispat etmiştir. Dolayısı ile boyutları yeniden ortaya koymak amacıyla keşfedici faktör analizi yapılmamıştır. Ölçeğin yapı geçerliliğinin ortaya konulması ve doğrulanması amacıyla Doğrulayıcı Faktör Analizi (DFA) yapılmıştır.

Doğrulayıcı faktör analizi (DFA), ölçek geliştirmek veya önceden geliştirilmiş bir ölçeğin yapı geçerliliğinin doğrulanması için kullanılan bir analiz yöntemidir. Yöntemde, belirlenmiş bir model çerçevesinde gözlenen değişkenlerden hareketle gizil değişken/değişkenler (faktör/faktörler) oluşturulması amaçlanır (Aytaç ve Öngen, 2012:16).

Doğrulayıcı faktör analizi neticesinde SERVQUAL ölçeğinin boyutları (gizil değişkenler) ile gözlenen değişkenler arasındaki ilişkinin yap1 geçerliliğinin olduğu ortaya koyulmuştur. Ancak, "güvenilirlik" boyutunun 4. ifadesi (G4) ve "heveslilik" boyutunun 1. ifadesi (H1) yapı geçerliliğini bozduğu için modelden çıkarılmıştır.

Muhasebe meslek mensuplarının sundukları hizmet neticesinde ortaya çıkan memnuniyeti ifade etmek üzere oluşturulan ölçek tek boyuttan oluştuğu için faktör analizi yapılmamıştır.

DFA neticesinde konfirme edilen hizmet kalitesi boyutları ile memnuniyeti ifade eden ölçeğin güvenilirliklerini ortaya koymak üzere Cronbach's Alpha değerleri hesaplanmış ve Tablo 2'de ifade edilmiştir. Tablodan anlaşılacağı üzere tüm boyutların güvenilirlikleri sağlıklı analizler yapılabilmesi için yeterlidir.

Tablo 2: Boyutların Güvenilirlik Sonuçları

\begin{tabular}{|c|c|c|}
\hline \multirow{2}{*}{ Değişkenler } & Boyutlar & $\begin{array}{c}\text { Güvenilirlik } \\
\text { (Cronbach's Alpha) }\end{array}$ \\
F1 & Hizmet Kalitesi & \\
\hline F2 & Fiziksel Özellikler (FzkOzl) & $\mathbf{8 3 , 3}$ \\
\hline F3 & & \\
\hline F4 & & \\
\hline
\end{tabular}




\begin{tabular}{|c|c|c|}
\hline G1 & \multirow{5}{*}{ Güvenilirlik (Gvnlir) } & \multirow{5}{*}{90,3} \\
\hline G2 & & \\
\hline G3 & & \\
\hline G5 & & \\
\hline G6 & & \\
\hline $\mathrm{H} 2$ & \multirow{4}{*}{ Heveslilik (Heves) } & \multirow{4}{*}{87,5} \\
\hline H3 & & \\
\hline $\mathrm{H} 4$ & & \\
\hline H5 & & \\
\hline GV1 & \multirow{4}{*}{ Güvenlik (Gvnlk) } & \multirow{4}{*}{81,5} \\
\hline GV2 & & \\
\hline GV3 & & \\
\hline GV4 & & \\
\hline E1 & \multirow{5}{*}{ Empati (Empti) } & \multirow{5}{*}{79,6} \\
\hline E2 & & \\
\hline E3 & & \\
\hline E5 & & \\
\hline E6 & & \\
\hline \multirow[t]{2}{*}{ Değişkenler } & Boyutlar & \multirow{2}{*}{$\begin{array}{c}\text { Güvenilirlik } \\
\text { (Cronbach's Alpha) }\end{array}$} \\
\hline & Memnuniyet & \\
\hline M1 & \multirow{6}{*}{ Memnuniyet (Memnyt) } & \multirow{6}{*}{92,4} \\
\hline M2 & & \\
\hline M3 & & \\
\hline M4 & & \\
\hline M5 & & \\
\hline M6 & & \\
\hline
\end{tabular}

\subsubsection{Korelasyon Analizi}

Hizmet kalitesi boyutlarının kendi aralarındaki ve memnuniyet boyutu ile aralarındaki ilişkiyi ortaya koymak amacıyla Pearson korelasyon analizi yapılmıştır. Analiz neticesinde, tüm boyutlar arasında \% 1önem seviyesinde pozitif yönlü anlamlı ilişkiler olduğu tespit edilmiştir. En yüksek düzeydeki ilişki $(0,755)$ hizmet kalitesi boyutlarından "güvenilirlik" ile müşterinin memnuniyet düzeyini ifade eden "memnuniyet" boyutu arasında gözlenirken, en düşük düzeydeki ilişki $(0,370)$ hizmet kalitesinin "güvenlik" boyutu ile "fiziksel özellikler" boyutu arasında tespit edilmiştir. Hizmet kalitesi boyutlarının tamamının memnuniyet ile ilişkili olması da çalışmanın amacına hizmet etmektedir. 
Tablo 3. Değişkenler Arası Korelasyon

\begin{tabular}{|c|c|c|c|c|c|c|c|}
\hline & & FizÖzlOrt & GüvenilirlikOrt & HeveslilikOrt & GüvenlikOrt & EmpatiOrt & MemnuniyetOrt \\
\hline \multirow[t]{3}{*}{ FizÖzlOrt } & PearsonCorrelation & 1 & ,639** &, $524^{* *}$ &, $370^{* *}$ &, $458^{* *}$ &, $572^{* * *}$ \\
\hline & Sig. (2-tailed) & & ,000 &, 000 & 000 & ,000 & ,000 \\
\hline & $\mathrm{N}$ & 215 & 215 & 215 & 215 & 215 & 215 \\
\hline \multirow[t]{3}{*}{ GüvenilirlikOrt } & PearsonCorrelation &, $639^{* *}$ & 1 &, $594^{* *}$ &, $559^{* *}$ & ,673** &, $755^{* *}$ \\
\hline & Sig. (2-tailed) &, 000 & &, 000 &, 000 & ,000 & ,000 \\
\hline & $\mathrm{N}$ & 215 & 215 & 215 & 215 & 215 & 215 \\
\hline \multirow[t]{3}{*}{ HeveslilikOrt } & PearsonCorrelation &, $524^{* *}$ &, $594^{* *}$ & 1 &, $740^{* *}$ & ,695** &, $528^{* * *}$ \\
\hline & Sig. (2-tailed) & ,000 & ,000 & & ,000 & ,000 & ,000 \\
\hline & $\mathrm{N}$ & 215 & 215 & 215 & 215 & 215 & 215 \\
\hline \multirow[t]{3}{*}{ GüvenlikOrt } & PearsonCorrelation & $370^{* *}$ &, $559^{* *}$ &, $740^{* *}$ & 1 & ,698*** &, $596^{* * *}$ \\
\hline & Sig. (2-tailed) &, 000 & ,000 & ,000 & & ,000 & ,000 \\
\hline & $\mathrm{N}$ & 215 & 215 & 215 & 215 & 215 & 215 \\
\hline \multirow[t]{3}{*}{ EmpatiOrt } & PearsonCorrelation &, $458^{* *}$ &, $673^{* *}$ &, $695^{* *}$ & ,698** & 1 &, $675^{* *}$ \\
\hline & Sig. (2-tailed) & ,000 & ,000 & ,000 & ,000 & & ,000 \\
\hline & $\mathrm{N}$ & 215 & 215 & 215 & 215 & 215 & 215 \\
\hline \multirow[t]{3}{*}{ MemnuniyetOrt } & PearsonCorrelation &, $572^{* *}$ &, $755^{* *}$ &, $528^{* *}$ &, $596^{* *}$ &, $675^{* *}$ & 1 \\
\hline & Sig. (2-tailed) & ,000 & ,000 & ,000 & ,000 & , 000 & \\
\hline & $\mathrm{N}$ & 215 & 215 & 215 & 215 & 215 & 215 \\
\hline
\end{tabular}

**. Correlation is significant at the 0.01 level (2-tailed).

\subsubsection{Yapısal Eşitlik Modeli}

Yapısal eşitlik modelleri (YEM), gözlenen değişkenler (observedvariable) ile örtük değişkenler (latentvariable) arasındaki korelasyon ilişkilerinin ve nedene dayalı ilişkilerin bir arada bulunduğu araştırma modellerinin test edilmesi ve yorumlanması için kullanılan güvenilir ve kapsamlı bir istatistiksel tekniktir (Dursun ve Kocagöz, 2010:3).

YEM analizinde oluşturulan modelin uygunluğunun, bir başka ifade ile elde edilen verilerin modeli ifade etmek için yeterli olup olmadığının ortaya konulması için çeşitli uyum iyiliği indeksleri kullanılmaktadır. Bunlar aşağıdaki gibi sıralanabilir (Arı, 2015:555):

1- $\quad$ Ki-kare/serbestlik derecesi $(\chi 2 / \mathrm{df})$

2- $\quad$ Uyum İyiliği İndeksi (Goodness of Fit Index-GFI)

3- $\quad$ Düzeltilmiş Uyum İndeksi (AdjustedGoodness of Fit Index- AGFI)

4- $\quad$ Normalleştirilmiş Uyum İyiliği İndeksi (TheNormed Fit Index- NFI)

5- $\quad$ Bağıl Uyum İndeksi (Relative Fit Index- RFI) 
6- $\quad$ Artmalı Uyum İndeksi (Incremental Fit Index- CFI)

7- Ortalama Hata Kök Yaklaşımı (Root-mean-squareerrorapproximationRMSEA).

İfade edilen ölçütlerin en çok kullanılanları ki-kare/serbestlik derecesi ( $\chi 2 / \mathrm{df})$, RMSEA (Ortalama Hata Kök Yaklaşımı) ve GFI (Uyum İyiliği İndeksi)'dir. Bunların yanında, CFI (Artmalı Uyum İndeksi) ve NFI (Normalleştirilmiş Uyum İyiliği İndeksi) değeri de çalışmalarda sıklıkla kullanılmaktadır(Arı, 2015:555; Cheng, 2001:653-654; SchermellehEngel vd., 2003:31-43).

Muhasebe meslek mensuplarının sunduğu hizmet kalitesinin boyutları olan fiziksel özellikler (FzkOzl), güvenilirlik (Gvnlir), heveslilik (Heves), güvenlik (Gvnlk) ve empatinin (Empti) müşteri memnuniyeti üzerindeki etkilerini ortaya koymak ve oluşturulan model aracılığı ile hipotezleri test etmek amacıyla LISREL programı aracılığı ile yapısal eşitlik modeli oluşturulmuş ve Şekil 2'de sunulmuştur.

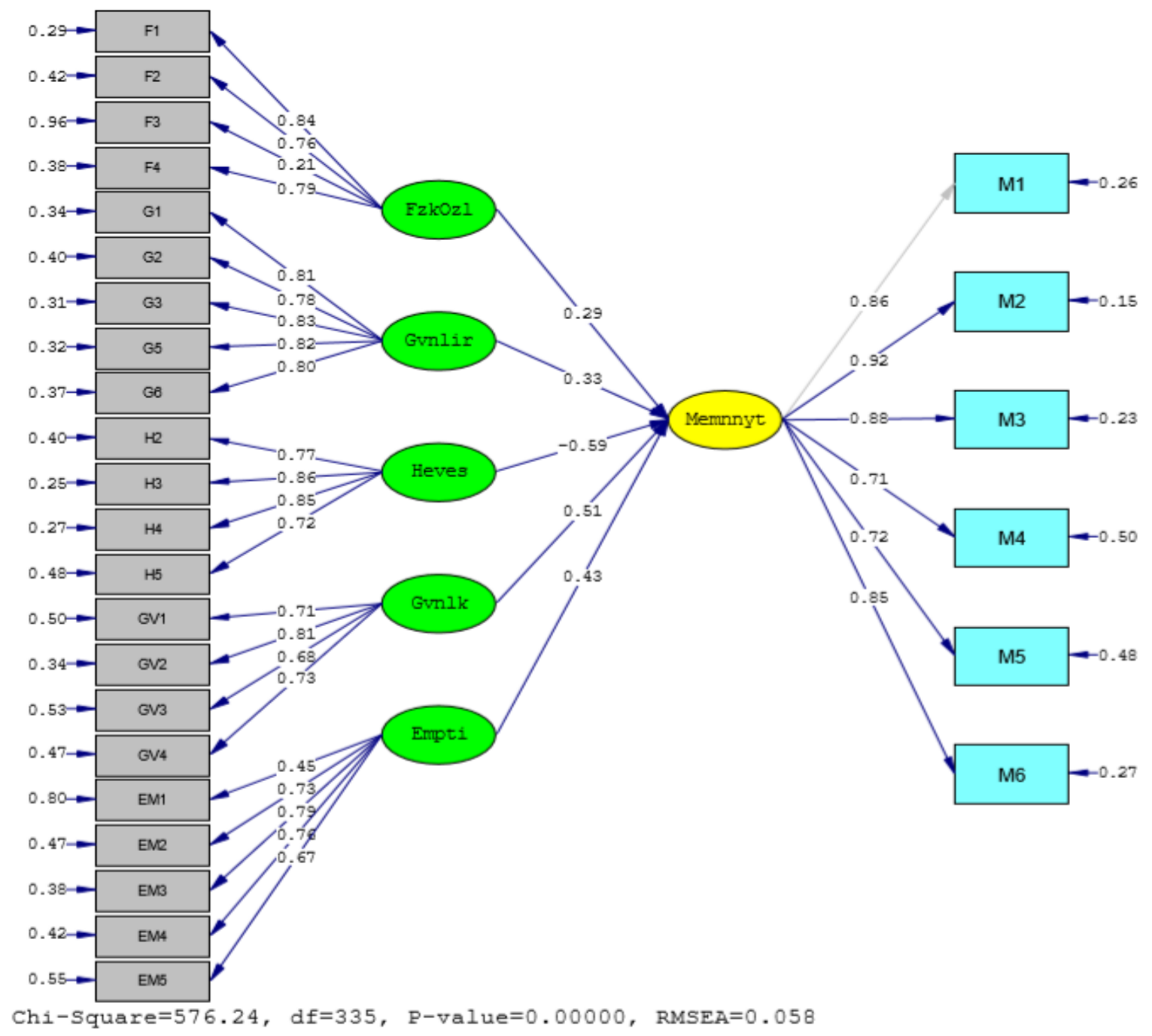

Şekil 2. Yapısal Eşitlik Modeli 
Uyum iyiliği indekslerinin referans aralıkları ve ortaya konulan modele ilişkin uyum iyiliği değerleri Tablo 4'de sunulmuştur.

Tablo 4. Uyum İyiliği İndeksleri Referans Aralıkları

\begin{tabular}{|l|c|c|c|}
\hline $\begin{array}{l}\text { Model } \\
\text { Uyum } \\
\text { Kriteri }\end{array}$ & İyi Uyum & Kabul Edilebilir Uyum & Çalışma Bulguları \\
\hline$\chi 2 / \mathrm{df}$ & $0 \leq \chi 2 / \mathrm{df} \leq 2$ & $2<\chi 2 / \mathrm{df} \leq 3$ & $576,24 / 335=\mathbf{1 , 7 2}$ (İyi uyum) \\
\hline RMSEA & $0 \leq R M S E A \leq 0,05$ & $0,05 \leq R M S E A \leq 0,08$ & $\mathbf{0 , 0 5 8}$ (Kabul edilebilir uyum) \\
\hline CFI & $0,97 \leq C F I \leq 1$ & $0,95 \leq C F I \leq 0,97$ & $\mathbf{0 , 9 9}$ (İyi uyum) \\
\hline NFI & $0,95 \leq N F I \leq 1$ & $0,90 \leq N F I \leq 0,95$ & $\mathbf{0 , 9 7}$ (İyi uyum) \\
\hline GFI & $0,95 \leq G F I \leq 1$ & $0,90 \leq G F I \leq 0,95$ & $\mathbf{0 , 9 0}$ (Kabul edilebilir uyum) \\
\hline
\end{tabular}

Kaynak: Schermelleh-Engel vd., 2003:52.

Yapısal modele göre, hizmet kalitesi boyutlarının müşteri memnuniyetine etki katsayıları şu şekilde tespit edilmiştir:

Fiziksel Özellikler (FzkOzl) $\rightarrow$ Müşteri Memnuniyeti (Memnnyt) $=0,29$

Güvenilirlik (Gvnlir) $\rightarrow$ Müşteri Memnuniyeti (Memnnyt) = 0,33

Heveslilik (Heves) $\rightarrow$ Müşteri Memnuniyeti (Memnnyt) = - 0,59

Güvenlik (Gvnlk) $\rightarrow$ Müşteri Memnuniyeti (Memnnyt) = 0,51

Empati (Empti) $\rightarrow$ Müşteri Memnuniyeti (Memnnyt) = 0,43

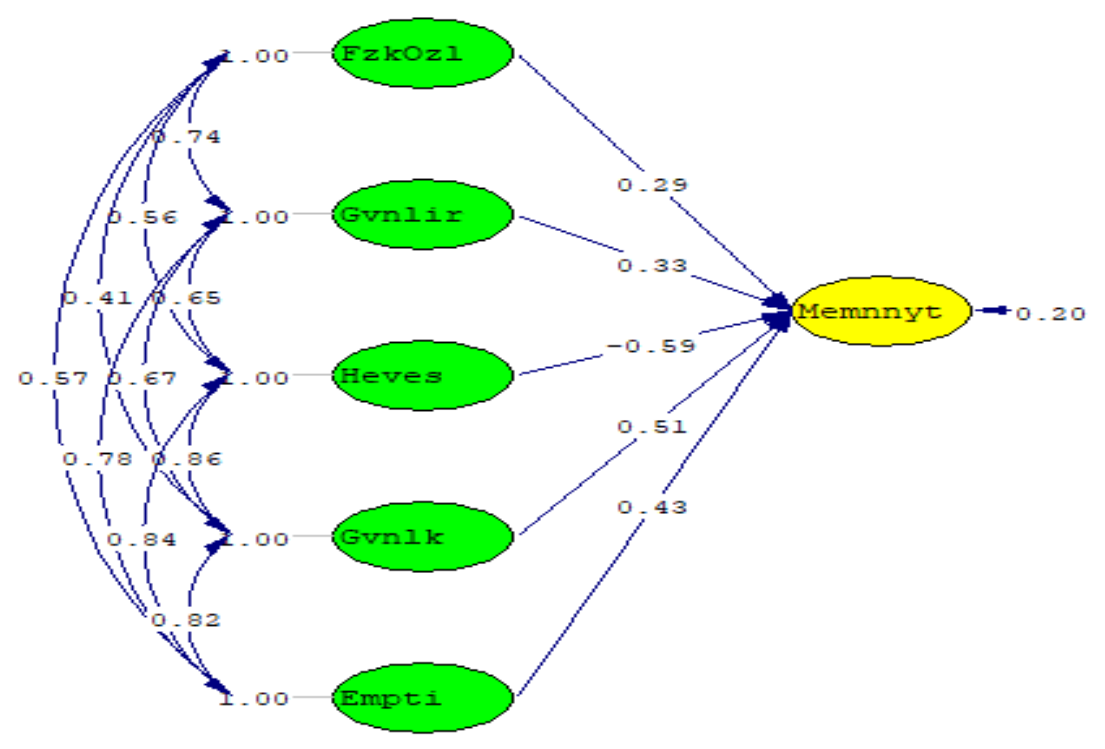

Chi-Square=576.24, df=335, P-value=0.00000, RMSEA=0.058

Şekil 3. Yapısal Eşitlik Modeli (Özet) 
Yapısal model sonuçları, muhasebe meslek mensuplarının sundukları hizmet kalitesinin boyutlarından fiziksel özellikler (FzkOzl), güvenilirlik (Gvnlir), güvenlik (Gvnlk) ve empati (Empti)'nin müşteri memnuniyeti üzerinde ayrı ayrı pozitif ve anlamlı etkisi olduğunu; hizmet kalitesinin heveslilik (Heves) boyutunun ise müşteri memnuniyetini negatif olarak etkilediğini göstermektedir. Yapısal model doğrultusunda çalışmanın hipotezlerinin test edilmesine ilişkin sonuçlar Tablo 5'te sunulmuştur.

Tablo 5. Yapısal Model Aracılığı ile Hipotez Test Sonuçları

\begin{tabular}{|c|c|c|c|}
\hline Ölçülen Etki & Standardize Regresyon Katsayıları & t değeri & Hipotez Sonucu \\
\hline FzkOzl $\rightarrow$ Memnnyt & 0,29 & 1,97 & $\mathbf{H}_{\mathbf{1} \mathbf{a}}:$ Kabul \\
\hline Gvnlir $\rightarrow$ Memnnyt & 0,33 & 1,98 & $\mathbf{H}_{\mathbf{1}}:$ Kabul \\
\hline Heves $\rightarrow$ Memnnyt & $-0,59$ & $-2,50$ & $\mathbf{H}_{\mathbf{1}}:$ Kabul \\
\hline Gvnlk $\rightarrow$ Memnnyt & 0,51 & 2,72 & $\mathbf{H}_{\mathbf{1 d}}:$ Kabul \\
\hline Empti $\rightarrow$ Memnnyt & 0,43 & 2,11 & $\mathbf{H}_{\mathbf{1} \mathbf{e}}:$ Kabul \\
\hline
\end{tabular}

$\mathrm{H}_{1 \mathrm{a}}$, muhasebe meslek mensuplarının sunduğu hizmet kalitesinin fiziksel özellikler boyutunun müşteri memnuniyetini etkilediğini ifade etmektedir. Modele göre, muhasebecinin hizmet sunumu sırasındaki fiziksel özellikleri müşteri memnuniyeti üzerinde pozitif bir etkiye sahiptir. Müşteriler, iyi giyimli, bürosu güzel dizayn edilmiş ve uygun teknolojiyi kullanan muhasebecilerden memnun olmaktadır.

$\mathrm{H}_{1 \mathrm{~b}}$, muhasebe meslek mensuplarının sunduğu hizmet kalitesinin güvenilirlik boyutunun müşteri memnuniyetini etkilediğini ifade etmektedir. Modele göre, muhasebecinin hizmet sunarken güvenilir olduğu hususunda müşterinin ikna olması memnuniyet düzeyini pozitif olarak etkilemektedir. Müșteriler, muhasebe hizmetlerinin zamanında ve doğru bir şekilde yürütülmesinden memnun olmaktadır.

$\mathrm{H}_{1 \mathrm{c}}$, muhasebe meslek mensuplarının sunduğu hizmet kalitesinin heveslilik boyutunun müşteri memnuniyetini etkilediğini ifade etmektedir. Ancak, bu etki diğer boyutların aksine ters yönlü bir etkiyi ifade etmektedir. Anket formunda boyutu oluşturan ifadeler incelendiğinde muhasebecinin çalışanları ile ilgili ifadelerden oluştuğu görülmektedir. Hem analiz sonuçları hem de yüz yüze görüşme yapılan bazı işletmelerden alınan geri dönüşler neticesinde, müşterilerin çalışanlardan daha çok muhasebecinin kendisi ile muhatap olmak istedikleri ve çalışanların sunduğu hizmet ne kadar iyi olursa olsun muhasebecinin kendisiyle muhatap olmadıklarında bu durumun memnuniyetlerini olumsuz etkilediği sonucuna ulaşılmıştır.

$\mathrm{H}_{1 \mathrm{~d}}$, muhasebe meslek mensuplarının sunduğu hizmet kalitesinin güvenlik boyutunun müşteri memnuniyetini etkilediğini ifade etmektedir. Modele göre, muhasebeci ve çalışanlarının müşterilerin mali bilgilerinin korunması hususunda güven telkin etmesi müşteri memnuniyetine pozitif katkı yapmaktadır.

$\mathrm{H}_{1 \mathrm{e}}$, muhasebe meslek mensuplarının sunduğu hizmet kalitesinin empati boyutunun müşteri memnuniyetini etkilediğini ifade etmektedir. Modele göre, muhasebeci ve çalışanlarının kendi çalışma düzenlerinin yanında müşterilerin çalışma düzenine uyumlu olarak hareket etmesi ve müşterinin menfaatlerini maksimum düzeyde koruyor olması müşteri memnuniyetine olumlu yansımaktadır. Müşteriler, ihtiyaçlarını bilen ve kendilerine kişisel ilgi gösteren muhasebecilerden memnuniyet duymaktadır. 
$\mathrm{H}_{1}$, araştırmanın ana hipotezini ifade etmektedir. Muhasebe meslek mensuplarının sunduğu hizmet kalitesinin boyutlarının müssteri memnuniyetini etkilediğini ifade etmektedir. Araştırma modelinin ortaya koyduğu sonuca göre, hizmet kalitesinin tüm boyutları müşteri memnuniyeti üzerinde etkilidir.

\section{SONUÇ}

Bir hizmet işletmesi olarak ifade edilen muhasebe meslek mensupları şüphesiz diğer işletmeler gibi serbest piyasada rekabet avantaj1 elde etmek isteyeceklerdir. Rekabet avantaj1 sağlamalarının en önemli araçlarından birisi ise yüksek düzeyde bir müşteri memnuniyeti elde etmektir. Sundukları hizmetler ile müşteri memnuniyetini tesis edebilen meslek mensuplarının tercih edilirliği artacak ve muhasebe hizmet sektöründe bir rekabet avantajı elde edeceklerdir.

Çalışmada müşteri memnuniyet düzeyinin tespiti yapıldığında Erzincan ili merkezinden faaliyet gösteren ve çalışmamıza katılan işletmelerin hizmet aldıkları muhasebe meslek mensuplarından \% 87 düzeyinde memnun oldukları tespit edilmiştir. Ortaya çıkan bu memnuniyet düzeyinin sürdürülebilirliğinin sağlanarak daha da yüksek seviyelere taşınması muhasebe meslek mensuplarının sundukları hizmet kalitesini sürdürülebilir kılmasına ve müşteri beklentileri çerçevesinde geliştirmesine bağlıdır. SERVQUAL ölçeğinin ortaya koyduğu hizmet kalitesi boyutları bu anlamda muhasebe meslek mensuplarına rehberlik edebilecektir.

Çalışmanın sonucunda, hizmet kalitesinin bütün boyutlarının müşteri memnuniyeti üzerinde olumlu ya da olumsuz etkisi olduğu ortaya çıkmıştır. Müşteri memnuniyetine pozitif olarak en yüksek düzeyli etkiyi $(0,51)$ hizmet kalitesinin güvenlik boyutu yapmaktadır. Özellikle, müşterilerin mali kayıtlarının ve ticari sırlarının korunması hususundaki hassasiyetleri güvenlik boyutunun yüksek etkisini izah edebilir. Müşteri memnuniyetine pozitif olarak en düşük etkiyi $(0,29)$ ise hizmet kalitesinin fiziksel özellikler boyutu yapmaktadır. Müşteriler muhasebecilerinden genel olarak iyi bir görünüş ve uygun bir teknoloji beklemekle birlikte öncelikleri dikkate alındığında bu beklentileri en sonda kalmaktadır. Müşteriler için öncelik verilerinin güvenliği, muhasebecilerinin kendi menfaatlerini gözlemesi, zamanında ve doğru işlemlere imza atmasıdır. Hizmet kalitesinin heveslilik boyutu ise müşteri memnuniyeti üzerinde diğer unsurlara nispeten daha yüksek (0,59 ) ancak olumsuz bir etkiye sahiptir. Bu durum müşterilerin en hassas olduğu hususlardan birinin doğrudan muhasebecinin kendisi ile muhatap olma istekleri olduğunu ifade edebilir. Muhasebecilerin, kendilerine rakip olabilecekleri endişesi ile çalışanlarını yetiştirme anlamında özenli davranmaması, kurumsallaşma adımlarında çalışanlar hususunda birtakım eksiklikleri olması bu sonucun olası nedenleri olarak ifade edilebilir.

Sonuç olarak ifade edilecek olursa, muhasebe meslek mensupları müşteri memnuniyetini elde etmek, memnuniyet düzeyini yükseltmek ve sürdürülebilirliğini sağlamak istiyorlarsa sundukları hizmetin kalitesini tesis etmeli, kalite düzeyini yükseltmeli ve bu durumu sürekli hale getirmelidir. Hizmet kalitesinin bütün unsurları önemli olmakla birlikte, muhasebeciler öncelikle çalışanlarını hizmet içi eğitimler yolu ile sürekli eğitmeli ve en az kendileri kadar donanımlı hale gelinceye kadar mümkün olduğu ölçüde müşterileri ile kendileri muhatap olmalı, müşterilerinin bilgi güvenliğine maksimum düzeyde ihtimam göstermeli, her ne kadar yasal mevzuatla müşteri talepleri arasında sıklıkla sıkışıyor olsalar da müşterilerinin penceresinden olaylara bakabilmeli ve kendini müşterinin yerine koyabilmeli, 
hizmetlerinin söz verdiği zamanda ve doğru bir şekilde sunmalı ve etkisi en az olsa bile fiziksel ve teknolojik imkânlarını geliştirmelidir.

\section{KAYNAKÇA}

Arı, Erkan (2015), “Öğretmenlerin İş Doyumlarının Mesleki Tükenmişlik Üzerine Etkisinin Yapısal Eşitlik Modeli İle Araştırılması", Uluslararası Sosyal Araştırmalar Dergisi, 8(39), ss. 549-565.

Aytaç, Mustafa - Öngen, Burcu (2012), "Doğrulayıcı Faktör Analizi ile Yeni Çevresel Paradigma Ölçeğinin Yapı Geçerliliğinin İncelenmesi”, İstatistikçiler Dergisi, Sayı 5, ss.14-22.

Banar, Kerim - Ekergil, Vedat (2010), "Muhasebe Meslek Mensuplarının Hizmet Kalitesi: Sunulan Hizmetlerin Kalitesi ile Müşteri Memnuniyeti İlişskisi Eskişehir Uygulaması”, Anadolu Üniversitesi Sosyal Bilimler Dergisi, 10(1),s s. 39-60.

Buttle, F.(1995), "Servqual: Review, Critque, Research Agenda”, European Journal of Marketing, Vol:30, No:1, (8-32).

Cheng, Eddie W.L. (2001), "SEM Being More Effective Than Multiple Regression in Parsimonious Model Testing for Management Development Research”, Journal of Management Development, 20(7), pp. 650-667.

Dursun, Yunus - Kocagöz, Elif (2010), "Yapısal Eşitlik Modellemesi ve Regresyon: Karşılaştırmalı Bir Analiz”, Erciyes Üniversitesi İIBF Dergisi, Sayı 35, ss. 1-17.

Ghobadian, A; Speller, S; Jones, M (1994), “Service Quality: Concepts and Models”, International Journal of Quality\&Reliability Managament, 11 (9), pp.43-66.

Goetsch, David L- Stanley B, Davis (1998), Undersatanding and Implementing ISO 9000 and ISO Standarts, Prentice -Hall, USA.

http://www.surveysystem.com/sscalc.htm

Kuriloff, Arthur- Hemphill, John M- Cloud, Douglas (1993), Starting and Managing the Small Business, McGraw-Hill Edition, Singapore.

Mucuk, İsmet (1994), Pazarlama İlkeleri, DER Yayınları, 6. baskı, İstanbul.

Parasuraman, A- Zeithaml, V.A- Berry, L.L (1985), “A Conceptual Model of Service Quality and Its Implications for Future Research”, Journal of Marketing, 49(4), pp.41-50.

Saxby, Carl L.- Ehlen, Craig R. - Koski, Timothy R. (2003), “The Relationship Of Service Qualityto Client Satisfaction In An Accounting Firm Setting”, International Business \&Economics Research Journal 2(3), March, pp.55-62. 
Schermelleh-Engel, Karin - Mossbrugger, Helfried - Müller, Hans (2003), "Evaluating The Fit of Structural Equation Models: Test of Significance and Descriptive Goodnessof-Fit Measures”, Methods of Psychological Research Online, 8(2), pp. 23-74.

Tek, Ömer Baybars (1999). Pazarlama İlkeleri, Beta Yayınları, İstanbul.

Yılmaz, Veysel - Çelik, Eray H. (2013), LISREL 9.1 ile Yapısal Eşitlik Modellemesi, Anı Yayıncılık, 3. Bask1.

Zeithaml, ValarieA- Parasuraman, A- Berry, Leonard L (1990), Delivering Quality Service: Balancing Customer Perceptions and Expectation, Free Press, USA. 